\title{
Data Envelopment Analysis Approach as a Complement to Resource-Use Efficiency Among Rice Farmers in Ogbomoso Agricultural Zone of Oyo State, Nigeria
}

\author{
Adedeji Israel Ajibade ${ }^{1}$, , Fabiyi Esther Funsho ${ }^{2}$, Adigun Grace Toyin ${ }^{1}$, \\ Oyetunde Timothy Oyeyemi ${ }^{3}$ \\ ${ }^{1}$ Agricultural Economics Department, Landmark University, Omu-Aran, Kwara State, Nigeria \\ ${ }^{2}$ Agricultural Extension Department, Landmark University, Omu-Aran, Kwara State, Nigeria \\ ${ }^{3}$ Oxford Policy Management, 5 Winipeg Close off Panama, Maitama Abuja
}

Email address:

ajibby77@gmail.com (A. I. Ajibade)

\section{To cite this article:}

Adedeji Israel Ajibade, Fabiyi Esther Funsho, Adigun Grace Toyin, Oyetunde Timothy Oyeyemi. Data Envelopment Analysis Approach as a Complement to Resource-Use Efficiency Among Rice Farmers in Ogbomoso Agricultural Zone of Oyo State, Nigeria. Journal of World Economic Research. Vol. 4, No. 2, 2015, pp. 23-31. doi: 10.11648/j.jwer.20150402.11

\begin{abstract}
This study examines the Data Envelopment Analysis Approach as a complement to resource-use efficiency among rice farmers in Ogbomoso agricultural zone of Oyo State. Data for the study were collected from 120 rice producers in seven villages in the study area pertaining to the 2012-13 crop season. Farm budgeting technique and production function analyses which incorporate the conventional neoclassical test of economic and technical efficiencies were used as the analytical techniques. The results of this study revealed that the farmers were inefficient in using the resources, rice seeds planted while fertilizers, labourer and agrochemicals were found to be under-utilized. The study recommends that appropriate adjustment is required for optimum allocation of resources and to maximize the revenue from the rice cultivation.
\end{abstract}

Keywords: Resource-Use Efficiency, Farm Budgeting Technique, Production Function Analyses

\section{Introduction}

Rice production is carried out with certain inputs or resources which enhance its productivity. The extent to which this productivity can be affected by these inputs depends on how the inputs are used. For instance, when a piece of land is being cultivated, its productivity will depend on the resources that are applied to it, but more importantly on how these resources are used or applied. Efficient use of resources has to do with the amount to be applied to the land in terms of quantities and their prices. That is to say the inputs must be applied in the quantities that would give the most output and at the same time the costs involved in using them must also be as low as possible. Hence, when the best resource is used in their right quantities and at the minimum possible cost to produce a certain output then efficient use of resources is achieved.

According to Yanggen et al., (1998), to increase rural incomes and meet growing food demands Sub-Saharan Africa (SSA) must improve agricultural productivity. SSA is the only developing region where per capita food production has been declining; the region now has the largest cereal deficits in the world. If there is no change in productivity, deficits will more than triple by 2020 .

Nigeria's socio-economic history and development has been very closely tied to its agricultural sector (Egbuna, 2008). The country is blessed with varied climatic zones, enormous resources, and has the potential of producing, processing, marketing and exporting different agricultural commodities. In Nigeria, before and immediately after independence, agriculture was the mainstay of the economy. However, its contribution to the economy have been declining since the oil boom of 1970's. The contribution of agriculture to Gross Domestic Product (GDP) which was $65 \%$ on the average in the 60's dropped to $22.4 \%$ between 1976 and 1980 even though it rose to about $39.2 \%$ in the year 2005 (CBN, 2006). This trend of agricultural contribution to GDP is not consistent with the expected role of agriculture as the economy develops.

Rice is a very important staple food in the diet of the estimated 160 million Nigerians. It is consumed in various forms but the most popular is as grains. The value of Nigeria's rice industry is estimated to be about US $\$ 5.86$ billion (as at 
2008) made up of US $\$ 2.2$ billion of imports and US $\$ 3.66$ billions of domestic production. The value of the industry is expected to rise to about US $\$ 7.98$ billions by 2010 at the current growth rate of $10 \%$ per annum. Nigeria is West Africa's largest producer of rice, producing an average of 3.2 million tons of paddy rice ( 2 million tons of milled rice) for the past 3 years. However, domestic supply has not kept pace with demand as imports have steadily increased faster than domestic supply by accounting for close to $60 \%$ of total supply.

One of the measures taken to address the problem of low supply is the call for rapid expansion of cereal production especially rice, in order to find a real basis for improvement in nutrition, especially among the people of Southern Nigeria who depended mainly on relatively inferior starch staple foods like Cassava, Yam, Cocoyam and Plantain. The Presidential initiative of the immediate past administration on rice is new production strategy for sustained increase in rice production for national self-sufficiency, food security and export promotion. This initiative has as its objective, the need to address the widening demand/supply gap and attain self sufficiency in rice production by 2015 and have surplus for export by 2017 .

The present federal government of Nigeria in her seven point agenda emphasized the rapid expansion in domestic production of rice in order to reduce annual importation of rice whose bills amounted to billions of naira and the bills can no longer be sustained by the national economy (CBN 2008). However, there is still persistent low yield and output of rice inspite of the government's efforts in ensuring availability of improved material inputs, modern technologies of rice farming and other production resources.

Efficiency of resource use, which can be defined as the ability to derive maximum output per unit of resource, is the key to effectively addressing the challenges of achieving food security. Raising productivity in agriculture will certainly lead to availability of food and reduce the real price of food while increased food production will have to come from increased yield. Production of rice in Nigeria is mainly in the hands of small scale farmers who are still using unimproved farming techniques. Actual yields of rice differ significantly from potential yields, and this has been attributed to low resource productivity.

For these reasons, the question therefore is, is it inefficient use of resources that results in low yields?

\section{Theoretical Review of Literatures}

Three types of efficiency are identified in the literature; these are technical efficiency, allocative efficiency and overall or economic efficiency (Farrell, 1957; Olayide and Heady, 1982). Technical efficiency is the ability of a farm to produce a given level of output with minimum quantity of inputs under a given technology. Allocative efficiency is a measure of the degree of success in achieving the best combination of different inputs in producing a specific level of output considering the relative prices of these inputs. Economic efficiency is a product of technical and allocative efficiency. In one sense, the efficiency of a farm is its success in producing as large amount of output as possible from given sets of inputs. In Farrell (1957) frame work, economic efficiency (EE) is an overall performance measure which is equal to the product of $\mathrm{TE}$ and $\mathrm{AE}$ (i.e. $\mathrm{EE}=\mathrm{TE} * \mathrm{AE}$ ). From Farrell analysis, a farm that is technically efficient in resource use operates on a production frontier, while a technically inefficient farm in resources use operates below the production frontier. Hence, the position of individual farm relative to the frontier could be influenced by factors ranging from climatic, socio-economic and marketing etc. Mathematically, Farrell's production frontier function begins by considering a stochastic production function with a multiplicative disturbance term of the farm:

$$
\mathrm{Y}=\mathrm{f}(\mathrm{Xa}, ; \beta) \mathrm{eE}
$$

Where $Y=$ output; $X=$ vector of input, $\beta=$ vector of parameter, $\mathrm{e}=$ error term; $\mathrm{E}$ is stochastic disturbance term consisting two independent element "V" and "U".

Thus,

$$
\mathrm{E}=\mathrm{U}+\mathrm{V}
$$

The symmetric element $V$ account for random variation in output quantity attributed to factors outside the farmer's control (such as disease, weather). A one - sided component $\mathrm{U}<\mathrm{O}$ reflects technical inefficiency relative to the stochastic frontier. Thus $\mathrm{U}=\mathrm{O}$ for farm output that lie on the frontier (i.e. $100 \%$ technical efficiency in resource use) and $\mathrm{U}<\mathrm{O}$ for farm output below the frontier as $\mathrm{N} \sim\left(\mathrm{o}, \mathrm{u}^{2} \mathrm{v}\right)$. Thus equation (1) becomes:

$$
Y=f(X a, ; b) e u+v
$$

Several empirical applications have followed the stochastic frontier specification. The first application of the frontier model to farm level data was by Battese and Coelli (1995) who estimated deterministic and stochastic Cobb-Douglas production frontier for the economics of scale in sheep production in Australia. The variance of the farm effects was found to be in a highly significant proportion of the value of sheep production in Australia and their study did not directly address the technical efficiency of farms. Similarly, Bagi (2004) employed the stochastic frontier Cobb-Douglas production function model to investigate differences in technical efficiencies of sole and mixed enterprise farm in West Tennessee and the study found that the variability of farm effects was highly significant. The mean technical efficiency of mixed enterprise farms was found to be smaller (0.76) than for sole crop farms

$(0.85)$ and the study show that, mixed enterprise farms were inefficient as compare to the sole crop farms as demonstrated by their various efficiency ratios.

The use of the stochastic frontier analysis in the study of agriculture in Nigeria is a recent developments. Such studies include that of Udoh (2003), Okike (2006) and Amaza (2000). Udoh (2003) used the Maximum Likelihood Estimation of the stochastic production function to examine the land 
management and resource use efficiency in South-Eastern Nigeria. The study found a mean output -oriented technical efficiency of $77 \%$ for the farmers, this indicates that farmers can still expand production by $23 \%$. The 0.98 indicates $98 \%$ for the most efficient farmers and 0.11 indicating $11 \%$ for the least efficient farmers. Okike (2006) investigated crop livestock interaction and economic efficiency of farmers in the Savanna Zones of Nigeria. The study found average economic efficiency of farmers are higher in the lowpopulation -low Market domain; Northern Guinea Sudan Savanna ecological zones; and crop -based Mixed Farmers farming system. Also Amaza (2000) work on small scale farm size and resource use efficiency in Kwara state, opined that, one of the means of proper utilization of farm inputs for greater efficiency is through farm size adjustment. The result was collaborated by the mean cost efficiency of 1.161 obtained from the data analysis which shows that an average farm in the sample area is about $16 \%$ above the frontier cost, indicating that they are relatively efficient in allocating their scarce resources.

\section{Material and Methods}

The study was conducted in July, 2012/2013 in Ogbomoso agricultural zone of Oyo state was carried out using a combination of structured interview schedule and personal interaction with the rice farmers. Multi-stage sampling technique was used to select 120 rice farmers to form the sample for the study. Three (3) local government areas namely Orire, Surulere, Ogooluwa were covered in the study. The socioeconomic characteristics of the rice farmers examined in the study are age, gender, farming experience, marital status and years of formal education.

Due to lack of market information regarding prevailing prices of the rice and its arrival etc., most of the producers marketed their produce in the village itself, without waiting for the better market opportunity. Gross margin analysis was employed to assess the profitability of rice production in the study area on an average basis. Gross margin (profit) according to Wood and Sangter (2002) is the excess of sales revenue over the cost of goods sold (variable cost). That is,

$$
\begin{gathered}
\mathrm{GM}=\mathrm{TR}-\mathrm{TVC} \\
\mathrm{TVC}=\mathrm{TOCI}+\mathrm{LI}
\end{gathered}
$$

Where GM is the gross margin, TR is total revenue, TVC is total variable cost, TOCI is total operating capital input, and LI is labour input. In this study, three different production functions, namely; linear, semi-log, and double $\log$ (Cobb Douglas) were employed to evaluate the productivity of key production factors for rice production in the study area, and the one that gave the best fit was chosen. The double-log function (Cobb- Douglas) provided the best fit and was therefore chosen for the study (Olomola, 1991; Mbata et al., 1993).

Using the ordinary least square (OLS) estimator, the production response function model was expressed implic- itly as:

$$
\mathrm{Y}=\mathrm{f}(1,2,3,4,5, \mathrm{Ui})
$$

Where

$\mathrm{Y}=$ the quantity of paddy in kilograms

$1=$ Land (farm size in hectares)

$2=$ Labour (man-days)

3 = quantity of fertilizer in kilograms

$4=$ volume of chemicals in litres

5 = quantity of seed in kilograms.

The functional form of the double-log function was expressed as follows:

$$
\operatorname{InY}=b_{0}+b_{1} \operatorname{In} X_{1}+b_{2} \operatorname{In} X_{2}+b_{3} \operatorname{In} X_{3}+b_{4} \operatorname{In} X_{4}+b_{5} \operatorname{InX} 5+e
$$

The marginal physical product (MPP) was given by:

$$
\mathrm{MP}_{\mathrm{P}_{\mathrm{i}}}=\mathrm{b}_{\mathrm{i}} \times \mathrm{AP}_{\mathrm{P}}
$$

Where $b_{i}=$ elasticities of the various inputs

$$
\operatorname{APP}_{\mathrm{i}}=\bar{Y} / \bar{X}
$$

Where $y$ is the mean of output and $x$ is the mean of factor inputs, and $b_{0}$ and $b_{i}$ are the constant and regression coefficients, respectively. Using the above specifications and the output and input prices, the marginal value products (MVPs) and allocative efficiency index (AEI) were computed as follows:

$$
\begin{gathered}
\operatorname{MVP}_{1}=\operatorname{MPP}_{\mathrm{i}} \mathrm{XP}_{\mathrm{y}} \\
A E I_{i}=\frac{\mathrm{MVP}_{\mathrm{i}}}{\mathrm{MFC}_{\mathrm{i}}}
\end{gathered}
$$

Where, $\mathrm{P}_{\mathrm{y}}$ and $\mathrm{MFC}_{\mathrm{i}}$, are the unit prices of output and factor input respectively. The decision of whether a resource is used efficiently or not, thus allocative efficiency, is based on the value of $\mathrm{AEI}_{\mathrm{i}}$. If $\mathrm{AEI}_{\mathrm{i}}$ is equal to one $\left(\mathrm{AEI}_{\mathrm{i}}=1\right)$, then the factor input is efficiently utilized, hence the farmer is considered allocative efficient (Hopper, 1965). The factor input is over-utilized if AEIi is less than $1\left(\mathrm{AEI}_{\mathrm{i}}<1\right)$ and under-utilized if $\mathrm{AEI}_{\mathrm{i}}$ is greater than unity $\left(\mathrm{AEI}_{\mathrm{i}}>1\right)$. The significance of each explanatory variable was determined using the t-test.

\section{Results and Discussion}

\subsection{Socio-Economic Characteristics of Selected Farmers in Ogbomoso Agricultural Zone of Oyo State, Nigeria}

The results of the socio-economics characteristics of the rice farmers are presented in Table 1 . The data have shown that rice farming is practiced by both men and women. Despite the fact that women perform many functions at home they still have the time and energy to be involved in rice farming. 
Table 1. Percentage Distribution of Socio-economic characteristics of the rice farmers in Ogbomoso agricultural zone of Oyo State

\begin{tabular}{|c|c|c|}
\hline Characteristics & $\begin{array}{l}\text { Numbers of rice } \\
\text { farmers }\end{array}$ & $\begin{array}{l}\text { Percentage of rice } \\
\text { farmers }\end{array}$ \\
\hline \multicolumn{3}{|l|}{ Age (in years) } \\
\hline $21-30$ & 10 & 8.3 \\
\hline $31-40$ & 21 & 17.5 \\
\hline $41-50$ & 44 & 36.7 \\
\hline $51-60$ & 30 & 25.0 \\
\hline Over 60 & 15 & 12.5 \\
\hline Mean Age & 47years & \\
\hline \multicolumn{3}{|l|}{ Sex } \\
\hline Male & 64 & 53.4 \\
\hline Female & 56 & 46.6 \\
\hline \multicolumn{3}{|l|}{ Educational Status } \\
\hline No formal education & 11 & 9.2 \\
\hline Primary education & 29 & 24.2 \\
\hline Secondary education & 48 & 40.0 \\
\hline Technical education & 17 & 14.1 \\
\hline Higher education & 15 & 12.5 \\
\hline \multicolumn{3}{|l|}{ Farming Experience } \\
\hline $1-5$ & 61 & 50.8 \\
\hline $6-10$ & 18 & 17.5 \\
\hline $11-15$ & 20 & 36.7 \\
\hline $16-20$ & 17 & 25.0 \\
\hline Over 20 & 4 & 12.5 \\
\hline \multicolumn{3}{|l|}{ Farm size $(\mathrm{Ha})$} \\
\hline$>1$ & 15 & 26.8 \\
\hline $1.1-1.9$ & 30 & 53.6 \\
\hline $2.0-2.9$ & 7 & 12.5 \\
\hline 3 and above & 4 & 7.14 \\
\hline Mean Farm Size & 2.6 & \\
\hline \multicolumn{3}{|l|}{ Household Size } \\
\hline $1-4$ & 15 & 26.8 \\
\hline $5-8$ & 28 & 50.0 \\
\hline $9-12$ & 9 & 16.1 \\
\hline 13 and above & 4 & 7.14 \\
\hline Mean Household Size & 6 & \\
\hline
\end{tabular}

$\mathrm{n}=120$

The women labour individually for the specific return of maintaining their obligations to feed their families either through growing food for consumption or food for sale to purchase the means to meet household obligation. The age distribution of the rice farmers has shown that $25 \%$ were below 40 years, while $62 \%$ were between 41 and 59 years and $13 \%$ of the rice farmers were above 60 years. This is an indication that farming in these areas is practised by all categories of young and elderly people living in the area.

The data on education are interesting, as only $9 \%$ of the rice farmers did not have any formal education. About $64 \%$ of the farmers have gone through primary and secondary education while $27 \%$ have had their higher diploma and degree. The educational status of the rice farmers would enable them to acquire knowledge and skill and thus increase their power of understanding. The farmers are well experienced in rice production; this is evident in their mean years of experience of (12.7) as rice farmers. The mean farm size was 2.6 hectares, this shows that rice farming is dominated by small scale farmers in the area. This limits their rice production potentials. Moreover, the mean household size of 6 persons was observed. This shows that the farmers had probably reasonable farm hands that could help in rice production. This is consistent with [Adegbite et al, 2008]. This implies that most of the farm hands (labour force) can be sourced within the household.

\subsection{Interpretation of the DEA Results in Ogbomoso Agricultural Zone of Oyo State}

Data envelopment analysis (DEA) has its origins in the seminar work by Charnes et al, (1978) who reformulated Farrells (1957) approach. In this study, DEA is described as a mathematical programming model applied to the observational data that provides a new way of obtaining empirical estimates of external relations such as the production functions and efficient production possibility surfaces that are at a cornerstone of modern economics. In general, DEA methodology uses a set of production unit of a sample to construct an efficiency frontier consisting of all possible linear combinations of efficient production unit. The frontier technology consists of convex input and output set enveloping the data point with linear facets.

For the purpose of this study, out of the six measures of relative efficiency (overall cost - minimizing efficiency, technical efficiency, allocative efficiency, pure technical, scale efficiency and efficiency due to input congestion) only technical efficiency is computed applying the input oriented model.

The main advantage of DEA is that it does not require specification of the functional form of the production, DEA calculations focus on individual observations in contrast to population averages. It can simultaneously utilize multiple outputs and multiple inputs with each being stated in different units of measurement. DEA also focuses on revealed best-practice frontier rather than on central tendency properties or frontier.

However, several properties that represent strengths in one capacity may act as limitation in another. One of the main criticisms of DEA is that the method does not at first sight have any statistical foundation i.e. that it is not possible to make reference about estimated DEA parameters, sensitivity, asymptotic properties etc.

Production is possible with a variety of factor of production proportion and production technologies. Often, several sizes of farms and techniques of production exist side by side in the same region. Where there are several production techniques, it is possible that the partial production elasticities (the estimated parameters of the function) will differ significantly among the different techniques. Consequently, valuable information has been lost. Many authors in the economic literature (Lau and Yotopolous (1971), Yotopolous and Nugent (1976), Doran (1985), Singh and Patel (1973) and Sharma(1983) have dealt with aforementioned problem. A common method used to assess these differences is dividing the sample into groups on the basis of some predetermined criteria. It is the alternative of categorizing the sample of farms by different production techniques. 
The same concept is also applied in this study. However, in this study relative technical efficiency is the classification criterion. Selection of the sub-samples is based on Date Envelopment Analysis (DEA). The sample has been divided according to the results from the application of DEA and subsamples for estimating separate production function are formed. This way of estimation procedures will lead to parameter estimates with clearer economic content.

Table 2 shows the initial sample of the farms from Ogbomoso agricultural zone of Oyo state which consisted of 120 farms. DEA was applied on this sample and the average technical efficiency for this group was 96.9 percent. A total of 92 of the farms included in the initial sample turned out to be technically inefficient which economically means a percent below 100. By excluding these 92 farms from the sample, a new sub-sample was constructed, which consisted of 28 farms. The same input oriented DEA model was applied to this sub-sample and the average technical efficiency for this group was also derived to be 99.9 percent. This time 16 farms were technically inefficient. By excluding these 16 farms from the sample of the second sub-sample was formulated, which included 12 farms. Again the same procedure was applied using input oriented DEA and all farms resulted to be technically efficient. The means that all 12 farm lie on the frontier.

Table 2. DEA Results for Ogbomoso Agricultural Zone of Oyo State

\begin{tabular}{llll}
\hline Northeast Zone & Total Samples (Number of farms) & Number of inefficient farms & Technical efficiency (Mean) \\
\hline Model I & 120 & 92 \\
Model II & 28 & 16 & 0.9690 \\
Model III & 12 & 12 & 0.9990 \\
\hline
\end{tabular}

The concept of technical efficiency refers to the producer's ability to avoid wasting resources by producing as much output as input usage allow, or by using as little input as output production allows.

An input-oriented evaluation seeks a projected point such that the proportional reduction in inputs is maximized. The primary concern of management implicitly this orientation is that the decision making unit (DMU) being evaluated keep operating with its current technique, characterized by the actual input ratios and gain efficiency by maintaining its current level of output and decreasing its inputs.

\subsection{Factor Elasticities of Cobb-Douglas Production Estimates for Ogbomoso Agricultural Zone Rice Farms of Oyo State}

Table 3 shows the results, signs and significances of estimates in MODEL I, MODEL II and MODEL III respectively. The Model I shows that the adjusted $R^{2}$ is 0.566 which implies that the model I could explain the total variation by $56 \%\left(\mathrm{R}^{2}=0.566\right)$. The model fitted was significant (Prob $>F=0.0000$ ). The variables that were significant included rice farm size (significant at $1 \%$ ) seed planted (significant at $1 \%$ ) while other input were all not significant at all know levels of significance. By implication, the above findings revealed that the major productive input that have a great impact on rice output when considering Model I were rice farm size and seed planted rice, farm size had the highest coefficient with a value of 0.829 in the Model I and by implication the farm size used existed as the most important input that impact rice output of the Model I farmers. Though for every unit increase in land used there is less than proportionate increase in rice output.

Table 3. Cobb-Douglas Production Function Estimation for Ogbomoso Agricultural Zone Rice Farms of Oyo State

\begin{tabular}{|c|c|c|c|c|c|c|c|c|c|}
\hline \multicolumn{4}{|l|}{ MODEL I } & \multicolumn{3}{|l|}{ MODEL II } & \multicolumn{3}{|l|}{ MODEL III } \\
\hline Variables & Coefficient & Std. Error & T-ratio & Coefficient & Std. Error & T-ratio & Coefficient & Std. Error & T-ratio \\
\hline Constant & 4.159 & 0.323 & 12.85 & 0.826 & 0.090 & 9.17 & 2.493 & 0.753 & 3.31 \\
\hline Rice farm size & 0.829 & 0.075 & $11.00 * * *$ & 0.832 & 0.092 & $8.96^{* * *}$ & 0.668 & 0.375 & $1.78^{*}$ \\
\hline Family Labour & 1.180 & 1.362 & 0.87 & 0.568 & 0.142 & $3.99 * * *$ & 3.846 & 11.013 & 0.35 \\
\hline Hired labour & 1.430 & 1.862 & 0.77 & 2.949 & 2.545 & 1.16 & 2.578 & 8.879 & 0.29 \\
\hline Seed planted & 0.819 & 0.072 & $11.27 * * *$ & 1.845 & 0.841 & $2.19 * *$ & 1.659 & 1.024 & $1.62 *$ \\
\hline Fertilizer & 0.564 & 1.933 & 0.29 & 3.234 & 0.569 & $5.68 * * *$ & 10.921 & 5.041 & $2.17 * *$ \\
\hline Herbicides & 0.469 & 2.607 & 0.18 & 0.614 & 4.697 & 0.13 & 3.683 & 1.488 & $2.48 * *$ \\
\hline \multicolumn{3}{|c|}{ Sum Squared Resid } & 13.98 & \multicolumn{2}{|c|}{ Sum Squared Resid } & 2.040 & \multicolumn{2}{|c|}{ Sum Squared Resid } & 0.835 \\
\hline \multicolumn{3}{|l|}{ R-squared } & 0.606 & \multicolumn{2}{|l|}{ R-squared } & 0.960 & \multicolumn{2}{|l|}{ R-squared } & 1.00 \\
\hline \multicolumn{3}{|c|}{ Adjusted R-squared } & 0.566 & \multicolumn{2}{|c|}{ Adjusted R-squared } & 0.911 & \multicolumn{2}{|c|}{ Adjusted R-squared } & 0.968 \\
\hline \multicolumn{3}{|l|}{$F(11,108)$} & 25.15 & \multicolumn{2}{|l|}{$\mathrm{F}(19,8)$} & 19.65 & \multicolumn{2}{|l|}{$F(6,5)$} & 1.64 \\
\hline \multicolumn{3}{|l|}{ P-value (F) } & 0.0000 & \multicolumn{2}{|l|}{ P-value (F) } & 0.0001 & \multicolumn{2}{|l|}{ P-value (F) } & 0.0000 \\
\hline \multicolumn{3}{|c|}{ Number of Observation } & 120 & \multicolumn{2}{|c|}{ Number of Observation } & 28 & \multicolumn{2}{|c|}{ Number of Observation } & 12 \\
\hline
\end{tabular}

* Indicates significance at the $10 \%$ level $\quad * *$ Indicates significance at the $5 \%$ level $* * *$ Indicates significance at the $1 \%$ level. 
In the Model II, the adjusted $\mathrm{R}^{2}$ is 0.911 which implies that overall Model II fitting was significant and could explain about $91 \%$ effect on rice production (Prob $>\mathrm{F}=0.0001$ ). The significant variables includes, rice farm size, family labour and fertilizer applied which were all significant at $1 \%$ while seed planted was significant at 5\%. The implication of the above finding is that the productive inputs that greatly impact on rice output of the Model II farmers were rice farm size, family labour, fertilizer and seed planted and among the above four major inputs, fertilizer has the highest coefficient with a value of 3.234 in the model I and therefore, it existed as the most limiting factor that greatly determine what rice output would be among the Model II farmers. The above findings were not conformed to a priori expectation and were in congruent to the findings of Kalirajan, (1981b).

In Model III, the adjusted $\mathrm{R}^{2}$ was 1.000 , the value are large and highly significant different from zero. This indicates a good fit of the Model III and the correctness of the specified distributional assumptions. The results of the estimated $\mathrm{R}^{2}$ shows that among all Model III appear to be the best according to Apezteguia and Garate (1997). The significant variables includes only rice farm size, seed planted, fertilizer and herbicides applied while other variables were not significant at all known levels of significance. The implication of the above finding is that regardless of the activities of the Model III farmers, the major limiting inputs of rice production were farm size, seed planted, fertilizer and herbicides applied. In the preferred Model III farm size, seed planted, fertilizer and herbicides applied had positive sign, it shows that the productive inputs that greatly impact on rice productivity in the Model III were farm size, seed planted, fertilizer (to boost the soil nutrient status of their marginal land available to rice production), herbicides applied (to curtail the adverse, economic effects of weed and herbs). Among the four major input, fertilizer has the highest coefficient with a value of 10.921 in the preferred Model III and therefore, it existed as the most limiting factor that greatly determine what rice output would be like among the Model III rice farmers. Those variables were all positive which implies that any increase in such variables would lead to a percentage increase of their elasticities in rice output.

\subsection{Interpretation of Variance Inflation Factor Analysis for Multicolinearity}

Assumption 10 of the classical linear regression model (CLRM) is that there is no Multicolinearity among the regression included in the regression model. According to Gujarati (2005), the term Multicolinearity is due to Ragnar Frisch. Originally it meant the existence of a perfect or exact linear relationship among some or all explanatory variables of a regression model.

The speed with which variance and covariance increase can be seen with the variance inflating factor (VIF) which is defined as

$$
V I F=\frac{1}{\left(1-r_{23}^{2}\right)}
$$

VIF show how the variance of an estimator is inflated by the presence of Multicolinearity. As $r_{23}^{2}$ approaches 1, the VIF approaches infinity. That is as the extent of colinearity increases the variance of an estimator increases and in the limit it can become infinite. VIF as a measure of collinearity is not free of criticism. A high VIF can be counter balanced by a low $\sigma^{2}$ or a high $\sum x^{2} j$. And to put it differently a high VIF is either necessary or sufficient to get high variance and high standard errors. Therefore, high Multicolinearity as measured by a high VIF, may not necessarily cause high standard errors.

One of the important assumption of the classical linear regression model is that the variance of each disturbance term $U_{i}$, conditional on the chosen values of the explanatory variables, is some constant number e qual to $\sigma^{2}$. This is the assumption of homoscedasticity, or equal (homo) spread (scedasticity), that is, equal variance.

Heteroscedasticity is likely to be encountered in crosssectional analysis. Heteroscedasticity can also arise as a result of the presence of outliers. An outlying observation, or outlier is an observation that is much different (either very small or very large) in relation to the observations in the sample. More precisely, an outlier is an observation from a different population to that which the remaining sample observation is generated. The inclusion or exclusion of such an observation, especially if the sample size is small can substantially alter the results of the regression analysis. Another source of heteroscedasticity arises from violating the assumption 9 of CLRM namely that the regression model is correctly specified.

For this study, White's test was used to test for the presence of heteroscedasticity while VIF (variance inflation factor) was used to test for the presence of Multicolinearity.

Table 4 shows that there is no problem of multi-colinearity for the preferred model III, VIF gave a value lower than 10 for all the explanatory variables considered in the model.

Any value of VIF that is greater than 10.0 strongly indicates the presence of multi-colinearity for such variable that is having VIF value greater than 10, the results of white's test for the northwest rice farmers shows that there is no problem of heteroscedasticity based on the fact the chi-square value obtained does not exceed the critical chi-square value.

The $5 \%$ critical chi-square value for $11 \mathrm{df}$ is 10.0705 , the $10 \%$ critical value is 8.1363 and the $25 \%$ critical value is 6.52468 . For all practical purposes, one can conclude, on the basis of white test, that there is no problem of heteroscedasticity. 
Table 4. Variance Inflation Factor Analysis for Multicolinearity in the Ogbomoso Agricultural Zone Rice Farms of Oyo State (Model III)

\begin{tabular}{ll}
\hline Variables & VIF \\
\hline Rice Farm size (ha) & 2.14 \\
Family labour (man-days) & 1.15 \\
Hired labour (man-days) & 2.95 \\
Seed planted (kg) & 1.97 \\
Fertilizer (kg) & 1.38 \\
Herbicides (litres) & 4.85 \\
Age (years) & 4.53 \\
Education level (years) & 3.15 \\
Farming experience (years) & 1.22 \\
Family size (number) & 1.41 \\
Extension contact (Number) & 3.22 \\
\hline
\end{tabular}

Variance Inflation Factor for Multicolinearity. Minimum possible value $=1.0$

Value $>10.0$ indicate a colinearity problem

\subsection{Marginal Physical Productivity of Rice Farms of Ogbomoso Agricultural Zone Rice Farms of Oyo State}

Having estimated the elasticity of output with respect to the physical inputs, it become necessary to evaluate the resource-use productivities. This is done by estimating the marginal and average physical productivities and their respective values. Table 5 shows the marginal value products of the input used in the production function analysis. It further shows that Model III marginal physical product has a better result results, based on the facts that they have the higher marginal product.

It is shown that family labour has 18.1 marginal physical values in the Model III compared to 11.6 in the Model II and 19.2 in the Model I. The above results show a decrease but of a very slow rate which implies that as the inefficiency is removed, productivity is falling, so family labour shows a better marginal physical product in the Model I.

Table 5 further revealed that hired labour has marginal product of 24.5 in the Model I, 63.4 in the Model II and 47.9 in the Model III. This also implies that the marginal physical product in good in Model II and this reveals that as the sample become more efficient the resource cost is decreasing to Model II and increasing again in Model III.

Fertilizer and Herbicides has a marginal physical product of 53.2 and 58.2 which is greater in Model III only. This implies that as the inefficiency, which is present in the sample under examination is obliterated the productivity is improved at a fast rate. It further shown fewer inputs are demanded for the production of the same out, there by releasing resources for other economic activities.

Table 5. Marginal Value Products of Factors Used by the Rice Farms in Ogbomoso Agricultural Zone Rice Farms of Oyo State.

\begin{tabular}{llll}
\hline Number of Farms & Model I 120 & Model II 28 & Model III 12 \\
\hline Sample Means & & & $203,000.00$ \\
Rice Yield (N/ha) & $192,000.00$ & $215,000.00$ & $11,454.55$ \\
Family labour (N/ha) & $11,778.00$ & $10,531.43$ & $10,914.87$ \\
Hired labour (N/ha) & $11,216.98$ & $10,002.63$ & 7346.91 \\
Seed Planted (N/ha) & 7402.14 & 6532.24 & $41,719.55$ \\
Fertilizer (N/ha) & $42,408.58$ & $37,872.86$ & $12,855.82$ \\
Herbicides (N/ha) & $23,763.78$ & $15,900.14$ & 18.1 \\
Marginal Products & & & 47.9 \\
Family labour (N/ha) & 19.2 & 11.6 & 45.8 \\
Hired labour (N/ha) & 24.5 & 63.4 & 53.2 \\
Seed Planted (N/ha) & 21.3 & 60.7 & 58.2 \\
Fertilizer (N/ha) & 2.55 & 18.4 & 8.31 \\
Herbicides (N/ha) & 3.79 & & \\
\hline
\end{tabular}

Source: Derived from Field Survey, 2010

\subsection{Resource Use Efficiency of the Rice Farms in Ogbomoso Agricultural Zone Rice Farms of Oyo State}

Table 6 shows results of input elasticities for each input in the Cobb-Douglas production function. One percent increase in the quantity of rice farm used will increase rice output by 0.668 percent, ceteris paribus. In addition, a one percent increase in the family labour and hired labour will increased rice output by 3.846 and 2.578 percent respectively. On the other, a one percent increase in seed rate and fertilizer applied will probably increase rice yield by 1.659 and 10.921 percent respectively while the one percent increase in herbicides will also increase the rice yield by 3.683 percent. The study also shows that rice yield has the highest responsiveness to fertilizer, followed by family labour and herbicides. 
Table 6. Marginal Value Product and Marginal Input Cost of the Rice Farms in the Ogbomoso Agricultural Zone Rice Farms of Oyo State.

\begin{tabular}{llllll}
\hline Variables & Family Labour & Hired Labour & Seed Planted & Fertilizer & Herbicides \\
\hline MODEL I (120) & & & & & \\
MVP & 1728.0 & 2205.0 & 1917.0 & 229.5 & 341.1 \\
MIC & 134.4 & 134.4 & 130.0 & 62.0 & 900.0 \\
Efficiency Ratio & 12.8 & 16.4 & 14.7 & 3.70 & 0.37 \\
Input Use & Under Utilisation & Under Utilisation & Under Utilisation & Under Utilisation & Over Utilisation \\
MODEL II (28) & & & & & 747.9 \\
MVP & 1044.0 & 5706.0 & 5463.0 & 1656.0 & 900.0 \\
MIC & 134.4 & 42.4 & 130.0 & 62.0 & 0.831 \\
Efficiency Ratio & 7.77 & 42.0 & 26.7 & Over Utilisation \\
Input Use & Under Utilisation & & Under Utilisation & Under Utilisation & \\
MODEL III (12) & & 4311.0 & 4122.0 & 4788.0 & 5238 \\
MVP & 1629.0 & 134.4 & 130.0 & 62.0 & 900.0 \\
MIC & 134.4 & 32.1 & 31.7 & 77.2 & 5.82 \\
Efficiency Ratio & 12.1 & Under Utilisation & Under Utilisation & Under Utilisation & Under Utilisation \\
Input Use & Under Utilisation & & & & \\
\hline
\end{tabular}

$\mathrm{MVP}=\mathrm{P}_{\mathrm{Y}} \mathrm{MPP} ; \mathrm{P}_{\mathrm{Y}}$ is the price of the output

$\mathrm{P}_{\mathrm{X}}=$ Input Price (MIC)

While MPP $=($ Input elasticity X Mean yield $) /$ Mean of input used

The summation of the partial elasticity of production with respect to every input for a homogenous function that all resources varied in the same proportion is 23.355. These represents the increasing returns to scale, therefore, an increase in all inputs by one percent increase rice yield by more than one percent.

Table 6 shows resources use efficiency of rice production of the southeast rice farmers of the preferred Model III. The resources efficiency indices for the rice farmers are presented in Table 6. Deriving from the economic theory which stipulates that point of perfect allocative efficiency exist where marginal value product (MVP) of resource input is at equilibrium, parity or unit, is one with its marginal input cost (MIC). Farmers with these ratios closer to one (unity) or one were adjudge to be more efficient in the utilization of that particular inputs. Based on the result in table 48, to estimate the resource use efficiencies of the rice farmers, the p-value derived from the regression results were used to estimate the ratios of the marginal value product (MVP) of each input to the inputs price or marginal input cost (MIC) of the factor input for rice farmers thus:

$$
r=\frac{M V P}{M I C}=1
$$

Where:

$\mathrm{r}=$ Efficiency of resource use

MVP $=$ Marginal Value Product of the Resource Input

MIC = Marginal Input Cost of the Resource Input

The results presented in Table 6 shows that rice farmers in southeast (Model III) were more efficient in the utilization of all the inputs based on the fact that the ratio of the marginal value product (MVP) to the marginal input cost (MIC). The implication of the above result show an indication that the rice farmer onModel III does not achieve absolute efficiency because they (farmers) under-utilized some inputs. Similar cases of under-utilization of variable inputs were also reported by Onyenweaku (1994), Nwakpu (2008), Olagoke (1991) and Iheke et al (2008).

\section{Conclusions and Recommendations}

The usual interpretation of the production function is that, although individual rice farms attempt to maximise profits, they are not uniformly successful in doing so due to differences in their technical and managerial abilities. Findings from this study conclude that rice farmers in Oyo State were technically inefficient in the use of farm resources. The inefficiency of the rice farmers may be directly or indirectly linked to the high cost of fertilizer and at time improved seed.

Production function obtained from Cobb-Douglas functional form (Model III) in Ogbomoso agricultural zone yielded the greater significance of fertilizer and farm size, and they were found under-utilised, which implies to make effective rearrangement of the available inputs basket to enhance the technical efficiency of rice farmers in Oyo State to some extent.

The concept of technical efficiency was developed to introduce systematic deviation in the quantities of inputs that farms use and in assumptions of maximising behaviour by farms that face the same product and factor prices. Given the empirical, the proposed recommendations are:

1. It is recommended that when working on the estimation of production function, the first thing is to thoroughly remove the inefficient firms with the help of a non-parametric approach, known as Data Envelopment Analysis. This helps to select the farms that utilize the existing technology efficiently by allowing the estimation of a production function that reveals the true input-output relationship.

2. Rice output shows a high responsiveness to farm size, hired labour, fertilizer and herbicides. Government should therefore continue to increase the subsidy on fertilizer, herbicides and even seeds and also try as much as possible to make those inputs available in smaller packaged bag. Government owned rural fertilizer market could also be put in place in each local government of the country in order to 
offset the exortionary effects of merchants who make the demand for fertilizer difficult for the farmers. The importation of fertilizer into the country should also be discouraged in order to reduce costs at local markets and encourage domestic production

3. Finally, the study recommends that more of the productive resources should be employed by the rice farmers for increase paddy rice production since all inputs are underutilized. It is recommended that the farmers be advised to use their inputs up to the point where the values of the marginal products (MVPs) equate their factor prices (i.e. $\operatorname{MVPs}=\mathrm{P}_{\mathrm{X}} \mathrm{s}$.

\section{References}

[1] Adegbite, D.A, Oluruntoba, O.A, Adubi, K.O, Shobanke, S.B (2008): Impact on National Fadama Development project II on small scale farmers' income in Ogun State. Implications for Agricultural Financing in Nigeria. Journal of Sustainable Development in Africa, Vol 10(3), 32-43

[2] Apezteguia, B.I. and Garate. M.R. (1997): Technical efficiency in the Spanish agrofood industry. Agricultural Economics, 17: 179-189.

[3] Amaza, P.S (2000): Efficiency of food crop production in Gombe State, Nigeria, Un-published PhD. Thesis, Department of Agricultural Economics, University of Ibadan, Ibadan.

[4] Bagi, F.S (2004): Stochastic frontier production function and farm-level technical efficiency of full - time and part-time farms in tennessee, N. Cent. J. Agric. Econ, Vol 6 (4), 48-55.

[5] C.B.N (2006): Central Bank of Nigeria, Statistical Bulletin, 10 (2006).

[6] C.B.N (2008): Central Bank of Nigeria, Statistical Bulletin, 23 (2008).

[7] Charnes A, Cooper WW, Rhodes E (1978): Measuring the Efficiency of Decision Making Units European Journal of Operational Research, Vol 2(6):429-444.

[8] Doran H. (1985): "Small" or "Large" Farm: Some Methodological Considerations, American Journal of Agricultural Economics. 67(1): 130-132.

[9] Egbuna, E.N. (2008): A review of the activities of the national strategic grains reserve: Issue arising, C.B.N Bullion, AprilJune, 2003, (2008), 42 -45.

[10] Farrell MJ (1957): The measurement of productive efficiency. Journal of the Royal Statistical Society, Vol 120:253-281.
[11] Gujrati DN. Basic econometrics. 3rd edition. McGraw-Hill Inc. 1995;237.

[12] Kalirajan, K (1981b): An Econometric Analysis of Yield Variability in Paddy Production. Canadian Journal of Agricultural Economics. 29: 283-294.

[13] Lau, L. J., and P. A Yotopolous, (1971): A test for relative efficiency and application to Indian. Agriculture American Economic Review, 61: 94 -109.

[14] Mbata, J. N. \& Matewa, J. C. (1983): "Resource Use Efficiency among Small-Scale Farmers in Selected Areas of Western Kenya", Trpenlandwirt, Germany, Vol. 94 (2).

[15] Okike, I (2006): Crop-livestock interaction and economic efficiency of farmers in the Savanna Zone of Nigeria, Unpublished Ph.D Thesis, Department of Agricultural Economics, University of Ibadan

[16] Olayide, S.O. and Heady, E.O. (1982): Introduction to Agricultural Production Economics, Ibadan University Press.

[17] Olomla, A. (1991): Capture Fisheries and Aquaculture in Nigeria: A Comparative Economic Analysis, Issues in Afri-can Rural Development, Vol. 1, Winrock Institute for Agri-cultural Development

[18] Sharma R, (1983): The Role of Institutional Credit in Nepalese Food Production,

[19] M. Tech. Thesis, University of New England.

[20] Singh R. and Patel R. (1973): Returns to Scale, Farm Size and Productivity in Meerut District, Indian Journal of Agricultural Economics 28: 43-47.

[21] Udoh, E.J (2003): Land management resources, Use efficiency among farmers in South Eastern Nigeria, Unpublished Ph.D Thesis, Department of Agricultural Economics, University of Ibadan.

[22] Wood, F., and Sangster, A. (2002): Business Accounting, 9th edition, Pearsons Education ltd, pp 66

[23] Yanggen, D., Kelly, V., Reardon, T., and Naseem, A. (1998): Incentives for Fertilizer Use in Sub-Saharan Africa: A Review of Empirical Evidence on Fertilizer Response and Profitability, MSU International Department of Agricultural Economics Development Department of Economics, Work-ing Paper No. 70, Michigan State University

[24] Yotopoulos P. and Nugent J., (1976): Economics of Development,(1976), New York, Harper- Row Publ. 